\title{
PENINGKATAN KUALITAS PEMBELAJARAN PRAKARYA DAN KEWIRAUSAHAAN MELALUI METODE CLTSMK
}

\author{
Galeh Nur Indriatno Putra Pratama \\ Fakultas Teknik Univesritas Yogyakarta \\ galehnurpp@gmail.com \\ Moch. Bruri Triyono \\ Fakultas Teknik Univesritas Yogyakarta \\ bruritriyono@yahoo.co.id
}

\begin{abstract}
Abstrak
Penelitian ini bertujuan untuk mengungkapkan: (1) peningkatan sikap belajar siswa dan (2) proses peningkatan kompetensi dasar mengidentifikasi sumber daya dan membuat desain karya rekayasa dengan penggunaan metode pembelajaran CLTSMK pada mata pelajaran Prakarya dan Kewirausahaan yang ditunjukkan melalui motivasi, kreativitas, dan kemampuan manajerial siswa kelas X Kimia Industri di SMKN 2 Depok. Penelitian ini merupakan PTK, mengacu pada model Kemmis \& Mc. Taggart. Penelitian terdiri atas siklus I-III melalui tahapan perencanaan, tindakan, pengamatan, dan refleksi. Subjek penelitian 32 siswa, kelas X Kimia Industri. Pengumpulan data menggunakan lembar observasi dan wawancara. Data dianalisis secara deskriptif. Hasil penelitian menunjukkan: (1) persentase rerata peningkatan siklus I-III sebesar 41,611\%, 36,053\%, dan 9,551\% tinjauan motivasi; 29,239\%, 40,458\%, dan 18,231\% tinjauan kreativitas; 30,774\%, 32,311\%, dan 16,996\% tinjauan kemampuan manajerial siswa dan (2) proses upaya peningkatan sikap belajar melalui motivasi, kreativitas, dan kemampuan manajerial siswa terdiri atas empat fase.
\end{abstract}

Kata kunci: pembelajaran prakarya dan kewirausahaan, CLTSMK, sikap belajar siswa.

\section{THE IMPROVEMENT OF THE QUALITY OF CRAFT AND ENTREPRENEURSHIP TEACHING THROUGH CLTSMK METHOD}

\begin{abstract}
This research aims to reveal: (1) the improvement of the learning attitude and (2) the process to the improvement of basic competencies in identifying resources and create an engineering work design by using CLTSMK learning method in Craft and Entrepreneurship subject shown by motivation, creativity, and managerial ability in Chemical Industry of class X students of SMKN 2 Depok. This research is classroom action research, design refers by Kemmis \& Mc. Taggart. This research consisted of cycle I-III, the stages of research consist of planning, action, observation, and reflection. The subject of this research was 32 class X students of Chemical Industry. The data were collected using observation and interview guides. The data were analyzed using descriptive analysis techniques. This research results showed: (1) the mean percentage improvement of the condition of cycle I-III subsequently are $41.611 \%, 36.053 \%$, and $9.551 \%$ for the observation of students' motivation; $29.239 \%, 40.458 \%$, and $18.231 \%$ for the observation of students' creativity; $30.774 \%$; $32.311 \%$; and $16.996 \%$ for the observation of students' managerial ability and (2) the process of improving the students' learning through motivation, creativity, and managerial ability consists of four phases.
\end{abstract}

Keywords: craft and entrepreneurship learning, CLTSMK, student learning attitude.

\section{PENDAHULUAN}

Mata pelajaran Prakarya dan Kewirausahaan merupakan mata pelajaran yang mengkombinasikan antara skill dan teknologi lalu dikemas dalam pembelajaran teori dan praktik (Presiden dalam Rencana Strategis Direktorat Jenderal Pendidikan Menengah Tahun 2010-2014, 2013, p.41). Nasution 
(2007, p.28) berpendapat, gabungan antara skill dan teknologi melalui jiwa wirausaha pada diri seseorang dapat didefinisikan sebagai technopreneurship. Technopreneurship merupakan kemampuan seseorang dalam berwirausaha dengan pemanfaatan teknologi.

Badan Pusat Statistik (BPS) tahun 2014 dapat dijelaskan persentase pengangguran siswa SMK tahun 2014 terjadi peningkatan sebesar 5,578\% dari jumlah pengangguran siswa SMK tahun 2013 sebesar 1,258 juta jiwa menjadi 1,332 juta jiwa. Jumlah lowongan kerja terdaftar di BPS tahun 2013 hanya sebesar 612.699 buah, pernyataan tersebut dikuatkan oleh Direktur Pembinaan SMK Mustaghfirin dalam Metrotv News, bahwa memang benar persentase angka pengangguran SMK di bulan Agustus tahun 2014 tertinggi sebesar 11,24\%.

Lulusan SMK apabila tidak terserap dalam Dunia Usaha dan Dunia Industri (DUDI) serta tidak memiliki keterampilan dalam berwirausaha maka akan menjadi beban negara. Berdasarkan fenomena tersebut, perlu suatu upaya nyata untuk mengurangi jumlah angka pengangguran lulusan SMK salah satunya dengan cara memaksimalkan peran pendidikan kewirausahaan. Pendidikan kewirausahaan di SMK dapat jadikan modal dasar bagi lulusan SMK untuk berwirausaha sesuai dengan kompetensi yang dimiliki, sehingga akan melahirkan tenaga terdidik yang terampil.

Pembelajaran kewirausahaan di SMK Negeri 2 Depok baru sebatas pada menjual suatu produk, bukan kepada pengembangan kemampuan berdasarkan pada kompetensi keahlian masing-masing. Salah satu tujuan mata pelajaran Prakarya dan Kewirausahaan adalah siswa dituntut untuk menghasilkan karya yang siap dimanfaatkan dalam kehidupan, bersifat pengetahuan maupun landasan pengembangan berdasarkan pemanfaatan teknologi kearifan lokal maupun teknologi terbarukan, serta menumbuh kembangkan jiwa wirausaha melalui melatih dan mengelola penciptaan karya (produksi), mengemas, dan menjual berdasarkan prinsip ekonomis, ergonomis, dan berwawasan lingkungan (Kementerian Pendidikan dan Kebudayaan, 2013, p.2).

Permasalahan yang muncul pada pembelajaran kewirausahaan melalui mata pelajaran
Prakarya dan Kewirausahaan di SMK Negeri 2 Depok adalah minimnya hasil produk siswa yang dihasilkan pasca mengikuti mata pelajaran Prakarya dan Kewirausahaan. Hal ini dijelaskan oleh salah satu guru pengampu mata pelajaran Prakarya dan Kewirausahaan kelas X di SMK Negeri 2 Depok, dari 10 kelas yang diampu belum semua kelas dapat menghasilkan desain/produk mata pelajaran Prakarya dan Kewirausahaan.

Pembelajaran yang selama ini digunakan oleh guru mata pelajaran Prakarya dan Kewirausahaan di SMK Negeri 2 Depok belum kepada pembentukan suatu keterampilan melalui berwirausaha, secara umum masih sebatas pada pemahaman tentang bagaimana cara menjual barang, serta memaksimalkan barang sehingga memiliki nilai jual.

Rendahnya kualitas pembelajaran menyebabkan siswa kurang termotivasi dalam mengikuti mata pelajaran Prakarya dan Kewirausahaan khususnya kelas X paket keahlian Kimia Industri. Hal ini ditunjukkan melalui rendahnya keaktifan siswa saat mengikuti kegiatan belajar mengajar di dalam kelas. Jarang terdapat respon aktif siswa melalui pertanyaan-pertanyaan ketika guru membuka sesi diskusi kelas pada mata pelajaran Prakarya dan Kewirausahaan. Selain itu, ketepatan siswa dalam menyelesaikan tugas yang diberikan oleh guru sering kali menjadi salah satu penghambat dalam pemenuhan materi ajar mata pelajaran Prakarya dan Kewirausahaan. Siswa sering mengalami kesulitan dalam mengeluarkan ide ketika diberi tugas membuat desain karya rekayasa sesuai topik pembelajaran saat itu.

Permasalahan di atas salah satunya disebabkan karena pengampu mata pelajaran Prakarya dan Kewirausahaan di SMK Negeri 2 Depok adalah guru non produktif, dimana siswa hanya dijelaskan mengenai cara berwirausaha. Selain itu, guru mata pelajaran Prakarya dan Kewirausahaan di SMK Negeri 2 Depok belum menguasai kompetensi sesuai strand (peminatan) kewirausahaan yaitu rekayasa.

Guru mata pelajaran Prakarya dan Kewirausahaan di SMK Negeri 2 Depok belum memiliki teknik penilaian yang sesuai, guna mengukur hasil belajar siswa yang terdiri dari kemampuan berproses, berproduk, dan kemampuan bersikap. 
Alternatif penyelesaian masalah yang dapat dilaksanakan untuk menyelesaikan beberapa permasalahan di atas adalah memberikan pelatihan kepada guru pengampu mata pelajaran Prakarya dan Kewirausahaan di SMK Negeri 2 Depok berupa diklat kewirausahaan peminatan rekayasa.

Melakukan kolaborasi pembelajaran pada mata pelajaran Prakarya dan Kewirausahaan antara guru kewirausahaan dengan guru produktif. Hal ini bertujuan untuk memberikan pendampingan kepada guru pengampu mata pelajaran Prakarya dan Kewirausahaan dalam menyampaikan materi ajar sesuai peminatan yaitu teknologi rekayasa.

Perlu metode pembelajaran yang tepat guna meningkatkan kualitas pembelajaran pada mata pelajaran Prakarya dan Kewirausahaan kelas X paket keahlian Kimia Industri di SMK Negeri 2 Depok, yaitu dengan menerapkan metode pembelajaran kooperatif (cooperative learning).

Ditinjau dari beberapa alternatif penyelesaian masalah di atas, maka dipilihlah satu tindakan yang bertujuan untuk meningkatkan kualitas pembelajaran melalui sikap belajar siswa dalam mengikuti mata pelajaran Prakarya dan Kewirausahaan kelas X paket keahlian Kimia Industri di SMK Negeri 2 Depok tahun ajaran 2014/2015 yaitu dengan penggunaan metode pembelajaran pembelajaran kooperatif (cooperative learning). Metode pembelajaran kooperatif akan dipadukan dengan pemanfaatan teknologi guna memaksimalkan proses pembelajaran dan sebagai salah satu sarana implementasi strand rekayasa dalam mata pelajaran Prakarya dan Kewirausahaan. Gabungan antara pembelajaran kooperatif dan pemanfaatan teknologi dalam pembelajaran ini disebut sebagai Cooperative Learning by Technopreneur for SMK (CLTSMK).

CLTSMKmerupakanmetodepembelajaran yang didasarkan pada pembelajaran kooperatif berbasis proyek dengan memanfaatkan teknologi untuk siswa SMK. CLTSMK menerapkan pembelajaran kolaborasi antar siswa dengan mayoritas pembelajaran pada unjuk kerja untuk meningkatkan kualitas pembelajaran melalui sikap belajar siswa dengan pemanfaatan teknologi.
Tujuan dari penelitian ini adalah mengungkapkanprosespeningkatankompetensidasar mengidentifikasi sumber daya dan membuat desain karya rekayasa dengan penggunaan metode pembelajaran CLTSMK pada mata pelajaran Prakarya dan Kewirausahaan yang ditunjukkan melalui motivasi, kreativitas, dan kemampuan manajerial siswa kelas X Kimia Industri di SMKN 2 Depok.

Entrepreneurship secara filosofis berarti pencipta atau pengelola usaha. Lastariwati (2012, p.73), kewirausahaan pada hakikatnya adalah ciri, sifat, dan watak seseorang yang memiliki kemauan untuk mewujudkan. Timmons (2008, pp.21-22) berpendapat, kewirausahaan merupakan bagian dari mobilitas ekonomi dan sosial, wirausahawan merupakan seorang pencipta, inovator, dan pemimpin serta inspirator bagi orang lain.

Kewirausahaan merupakan hasil dari proses disiplin dan sistematis dalammenerapkan kreativitas serta inovasi terhadap kebutuhan serta peluang pasar, termasuk menerapkan strategi terhadap ide dan pandangan baru untuk menciptakan produk atau jasa yang memuaskan kebutuhan pelanggan atau bersifat memecahkan masalah. Ciri seorang wirausaha dapat diidentifikasi melalui sikap seorang wirausaha yang dilihat dari kegiatan seharihari, antara lain: disiplin, berkomitmen tinggi, jujur, kreatif, inovatif, motivasi tinggi, mandiri, realistis, dan mampu memanajerial diri sendiri dan orang disekitarnya.

Technopreneurship merupakan penggabungan dari dua kata yakni teknonologi dan enterpreneur. Nasution (2007, p.28), berpendapat technopreneurship merupakan bagian dari entrepreneurship yang menekankan pada kemampuan memanfaatkan teknologi. Jusoh (2011, p.25) berpendapat, technopreneur dapat bermanfaat untuk pengembangan sektor usaha kecil dan menengah, technopreneur merupakan seseorang yang mampu membuat, berkreasi, dan berinovasi atas produk yang akan dijual ke pasar dengan pemanfaatan teknologi.

Buku panduan Direktorat Akademik Dikti dalam Direktorat Jenderal Pendidikan Tinggi (2008, p.7), menyatakan ada tiga komponen utama pembentuk karakter technopreneur 
antara lain: intrapersonal, interpersonal, dan extrapersonal dimana technopreneurship secara umum mengacu pada pemanfaatan teknologi untuk pengembangan dibidang wirausaha. Technopreneurship diibaratkan sebagai inkubator bisnis berbasis teknologi, yang memiliki wawasan untuk menumbuh kembangkan jiwa wirausaha di kalangan generasi muda (Hartono, 2011, p. 2).

Dapat disimpulkan bahwa technopreneurship merupakan kemampuan seseorang dalam mengembangkan jiwa wirausaha dengan pemanfaatan teknologi baik dalam proses pembuatan maupun pemasaran yang sesuai dengan kompetensi keahlian masing-masing. Batasan technopreneur yang ditinjau adalah pemanfaatan teknologi sebagai tool dalam proses berwirausaha sesuai dengan kompetensi keahlian yang dimiliki.

Motivasi berasal dari kata motif, dapat diartikan sebagai kekuatan yang terdapat dalam diri individu serta dapat menyebabkan individu tersebut bertindak. Motivasi tidak dapat diamati secara langsung tetapi dapat diinterpretasikan dalam tingkah laku yang berupa rangsangan, dorongan, atau pembangkit tenaga munculnya suatu tingkah laku tertentu (Sardiman, 2012, p.75).

Tanpa motivasi, seseorang tidak akan memiliki gairah dalam berusaha pencapaian, sebaliknya dengan motivasi yang tinggi, seseorang akan tertarik dan terlibat aktif bahkan berinisiatif dalam proses mencapai pemahaman.

Definisi motivasi dalam penelitian ini merupakan suatu kekuatan/keinginan dari dalam diri seseorang yang dapat menimbulkan dan mendorong untuk melakukan tindakan berwirausaha dengan memanfaatkan teknologi sesuai kompetensi keahlian yang dimiliki melalui kegiatan pembelajaran. Motivasi belajar siswa dalam bertechnopreneurship dapat dilakukan melalui pengamatan terhadap perilaku belajar siswa. Aspek-aspek yang diamati pada penelitian ini antara lain: sikap mencari peluang, sikap dalam memilih keterampilan, sikap berani mengambil risiko, dan sikap ambisi dalam mencapai tujuan.

Kreativitas identik dengan sesuatu yang baru, serta bagian dari suatu inovasi (Piirto,
2011, p.1). Pope (2005, p.27) mengistilahkan kreativitas sebagai penerapan pengetahuan dan keterampilan dalam cara-cara baru untuk mencapai tujuan. Kreativitas juga dapat bermakna sebagai kreasi terbaru dan orisinil, sebab kreativitas merupakan suatu proses mental yang unik untuk menghasilkan sesuatu yang baru, dan berbeda.

Lau (2011, p.216) berpendapat, kreativitas berpikir merupakan kemampuan berpikir seseorang tentang sesuatu dengan cara baru dan tidak biasa serta menghasilkan solusi yang unik. Dapat dikatakan kreativitas akan muncul dikarenakan dorongan diri sendiri untuk menyelesaikan permasalahan yang ada, disamping itu merupakan hasil dari gagasan/ ide baru.

Kreativitas dari sudut pandang technopreneur adalah kemampuan yang dimiliki seseorang dalam melahirkan suatu gagasan, metode, maupun produk baru yang dapat mendorong melakukan kegiatan berwirausaha dengan memanfaatkan teknologi sesuai kompetensi keahlian yang dimiliki melalui kegiatan pembelajaran. Indikator kreativitas berpikir, terdiri atas: sikap berinovasi, berorientasi pada tim/kelompok, keterbukaan, dan percaya diri.

Kelly (2011, p.1), berpendapat manajemen merupakan suatu kemampuan yang harus dimiliki seseorang guna mengelola semua proses yang ada didalamnya untuk mencapai suatu tujuan. Kemampuan manajerial terbentuk dari hasil konstruktif sosial yang digunakan untuk menyelesaikan suatu permasalahan melalui proses (Kearins, 2003, p.192).

Andler (2011, p.42), berpendapat bahwa manajemen merupakan salah satu komponen penting dalam mengelola/menjalankan suatu bisnis, dimana akan selalu berkembang dari waktu ke waktu serta akan menyesuaikan dengan keahlian dan kebutuhan masingmasing. Seseorang yang memiliki kemampuan manajemen, harus bertanggung jawab terhadap semua proses yang dilakukan, mulai dari perencanaan hingga evaluasi (Ben-Daya, 2009, p.592).

Kemampuan manajerial dalam penelitian ini adalah kemampuan diri seseorang dalam hal mengelola jenis pekerjaan yang dapat 
mendukung kemampuan berwirausaha dengan memanfaatkan teknologi sesuai dengan kompetensi keahlian melalui kegiatan pembelajaran. Apabila ditinjau dari kemampuan manajerial siswa, maka terdiri atas: kemampuan siswa dalam berkelompok dan kemampuan siswa dalam mengelola waktu dalam pembelajaran.

Indikator kemampuan manajerial siswa, antara lain: kemampuan berkelompok terdiri dari mudah berkoordinasi, dapat bekerja secara kelompok, serta dapat saling membackup, dan kemampuan mengelola waktu terdiri dari tepat waktu, bekerja sesuai waktu, serta dapat menggunakan waktu yang telah diberikan.

Pembelajaran kooperatif adalah salah satu bentuk pembelajaran yang didasarkan oleh paham konstruktivisme (Slavin, 2005, pp.45). Pembelajaran kooperatif merupakan salah satu metode pembelajaran yang dinilai cukup efektif untuk mengatasi permasalahan kelas seperti mengefektifkan pembelajaran antara teori dengan pemahaman-pemahaman praktik secara tidak langsung secara kelompok (Yusuf, 2012, p.2).

Tujuan utama pembelajaran kooperatif sangatlah berbeda dengan kelompok tradisional yang menerapkan sistem kompetisi, dimana keberhasilan individu diorientasikan pada kegagalan orang lain. Sedangkan tujuan dari pembelajaran kooperatif adalah menciptakan situasi dimana keberhasilan individu ditentukan atau dipengaruhi oleh keberhasilan kelompoknya (Slavin, 2005, pp.8-9). Beberapa ahli pendidikan berpendapat bahwa metode pembelajaran kooperatif unggul dalam membantu siswa memahami konsepkonsep sulit.

Pembelajaran kooperatif merupakan metode pembelajaran dengan melibatkan sejumlah siswa sebagai anggota kelompok kecil yang memiliki tingkat kemampuan berbeda, dimana setiap siswa anggota kelompok harus saling bekerja sama dan saling membantu untuk mengikuti kegiatan pembelajaran di dalam suatu kelas. Metode pembelajaran kooperatif dalam penelitian ini menggunakan pendekatan pembelajaran berbasis project.

Metode pembelajaran Cooperative LearningbyTechnopreneurforSMK(CLTSMK) menerapkan pembelajaran kolaborasi antar siswa dengan mayoritas pembelajaran pada unjuk kerja. Kompetensi technopreneurship yang digunakan pada metode pembelajaran ini adalah kemampuan siswa dalam berproses (mengikuti pembelajaran) untuk menghasilkan suatu desain/produk sesuai kompetensi siswa dengan memanfaatkan teknologi digital di sekolah.

Peningkatan kualitas pembelajaran pada mata pelajaran Prakarya dan Kewirausahaan yang ditinjau adalah melalui sikap belajar siswa yang terdiri atas motivasi, kreativitas, dan kemampuan manajerial siswa.

Pelaksanaan metode pembelajaran CLTSMK didesain pada kompetensi dasar identifikasi sumber daya yang dibutuhkan dalam mendukung proses produksi karya rekayasa sebagai alat komunikasi sederhana serta membuat desain karya rekayasa alat komunikasi sederhana dengan sumber arus listrik DC. Tindakan yang diberikan pada implementasi terdiri atas fase 1 hingga fase 4 .

Peningkatan kualitas pembelajaran pada mata pelajaran Prakarya dan Kewirausahaan kelas X paket keahlian Kimia Industri di SMKN 2 Depok ditinjau pada sikap belajar siswa melalui motivasi, kreativias, dan kemampuan manajerial siswa.

\section{METODE PENELITIAN}

\section{Jenis Penelitian}

Jenis penelitian ini adalah classroom action research (penelitian tindakan kelas). Model yang digunakan dalam penelitian tindakan kelas ini menggunakan model yang dikembangkan oleh Kemmis \& Mc. Taggart terdiri atas perencanaan, tindakan, pengamatan, dan refleksi. Penelitian ini terdiri atas pra siklus, siklus I, siklus II, dan siklus III.

\section{Waktu dan Tempat Penelitian}

Penelitian ini dilakukan di SMK Negeri 2 Depok, Sleman. Waktu penelitian dilaksanakan pada semester genap tahun pelajaran 2014/2015 tepatnya pada bulan Oktober-November tahun 2014. 


\section{Subjek Penelitian}

Subjek penelitian ini adalah 32 siswa kelas X paket keahlian Kimia Industri yang mengikuti mata pelajaran Prakarya dan Kewirausahaan di SMK Negeri 2 Depok pada tahun ajaran 2014/2015.

\section{Prosedur}

Penelitian tindakan kelas ini dilakukan secara kolaboratif antara dua orang atau dua pihak dalam hal ini ialah guru dan peneliti. Peneliti berkolaborasi dengan guru pengampu mata pelajaran Prakarya dan Kewirausahaan untuk melakukan tindakan kelas, disamping itu penelitian ini melibatkan kolaborator untuk melakukan pengamatan terhadap perubahan sikap belajar dalam kelas tersebut.

Tolok ukur keberhasilan penelitian ini, salah satunya ditinjau melalui pencapaian minimal $75 \%$ dari jumlah total siswa dalam hal peningkatan sikap belajar siswa yang ditunjukkan melali motivasi, kreativitas, dan kemampan manajerial siswa. Desain penelitian ini dapat digambarkan sebagai berikut:

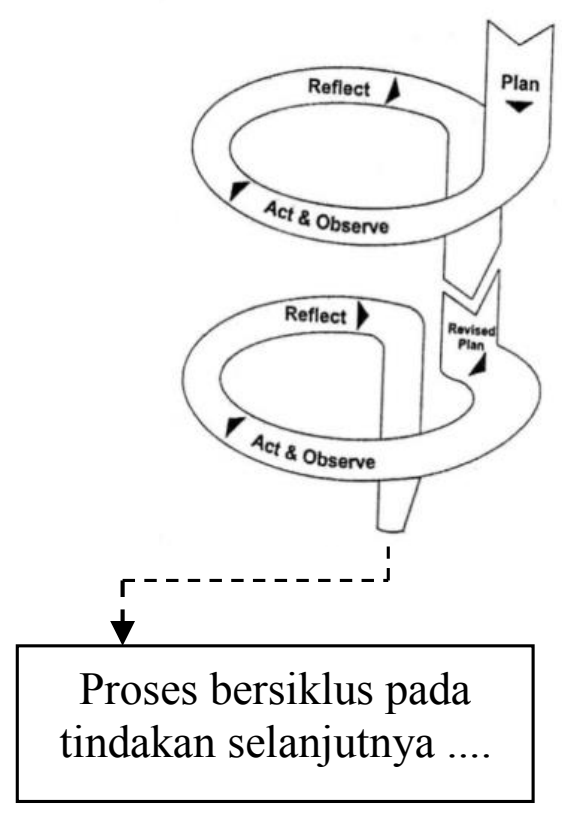

Gambar 1. Model Kemmis \& Mc Taggart (Rochiati, 2006, p.66)

\section{Pengumpulan dan Teknik Analisis Data}

Pengumpulan data menggunakan lembar observasi dan pedoman wawancara. Instrumen sebelum digunakan telah diuji validasi terlebih dahulu, melalui expert judgment dan uji reliabilitas dengan menggunakan uji antar rater melalui Cohens Kappa. Alternatif jawaban yang tersedia pada lembar observasi pengamatan sikap belajar siswa yang ditunjukkan melalui motivasi, kreativitas, dan kemampuan manajerial siswa menggunakan skala Likert. Data pada penelitian ini dianalisis menggunakan teknik analisis deskriptif.

\section{Hasil Penelitian dan Pembahasan}

Sikap belajar siswa yang ditunjukan melalui motivasi, kreativitas, dan kemampuan manajerial siswa dalam menghasilkan desain maupun produk pada mata pelajaran Prakarya dan Kewirausahaan pada kelas X Kimia Indusri tergolong relatif rendah. Hal ini terlihat dari sikap siswa yang terkesan kurang bersemangat dalam mengerjakan tugas, siswa enggan untuk bertanya kepada guru jika mengalami kesulitan, minim diskusi ketika proses pembelajaran berlangsung, serta pengumpulan tugas diluar waktu sehingga menyebabkan penyampaian materi pembelajaran tidak sesuai jadwal.

Pernyataan di atas diperkuat dengan hasil pra observasi yang dilakukan melalui pendekatan sikap belajar siswa yaitu motivasi, kreativitas, dan kemampuan manajerial siswa. Adapun hasil sikap belajar siswa yang ditunjukan melalui motivasi siswa pada pra siklus diperoleh harga mean $(\mathrm{M})=23,38$; median $(\mathrm{Me})=21$; modus $(\mathrm{Mo})=21$; standar $\operatorname{deviasi}(\mathrm{SD})=5,091$.

Hasil observasi pra siklus sikap belajar siswa yang ditunjukan melalui kreativitas siswa diperoleh harga mean $(\mathrm{M})=19,75$; median $(\mathrm{Me})=18$; modus $(\mathrm{Mo})=17$; standar deviasi $(\mathrm{SD})=4,127$. Hasil observasi pra siklus sikap belajar siswa yang ditunjukan melalui kemampuan manajerial siswa diperoleh harga mean $(\mathrm{M})=13$; median $(\mathrm{Me})=12$; modus $(\mathrm{Mo})=11$; standar deviasi $(\mathrm{SD})=3,080$.

Tindakan yang diberikan pada siklus I merupakan hasil dari diagnosis permasalahan yang terjadi saat kondisi pra siklus. Secara umum siklus I terdiri dari beberapa tahapan antara lain perencanaan, pelaksanaan tindakan, observasi dan refleksi.

Permasalahan yang muncul saat kondisi pra siklus pada aspek tinjauan motivasi 
siswa adalah siswa terlihat pasif dalam mengikuti kegiatan pembelajaran, siswa kurang memperhatikan materi pelajaran yang disampaikan oleh guru, serta siswa kurang percaya diri dengan penguasaan materi pembelajaran yang akan disampaikan.

Permasalahan yang muncul saat pra siklus pada aspek tinjauan kreativitas siswa adalah siswa merasa kesulitan dalam memunculkan ide yang berkaitan dengan materi pelajaran dan siswa hanya berpedoman pada contoh yang diberikan oleh guru saja. Disamping itu, permasalahan yang muncul saat pra siklus pada aspek tinjauan kemampuan manajerial siswa antara lain siswa tidak tepat waktu dalam pengumpulan tugas yang diberikan oleh guru dan siswa sering mengandalkan siswa lain dalam menyelesaikan tugas kelompok.

Dari hasil observasi siklus I pada sikap belajar siswa yang ditunjukan melalui motivasi siswa diperoleh harga mean $(\mathrm{M})=39,88$; median $(\mathrm{Me})=39$; $\operatorname{modus}(\mathrm{Mo})=38$; standar deviasi $(\mathrm{SD})=2,152$. Hasil observasi siklus I pada sikap belajar siswa yang ditunjukan melalui kreativitas siswa diperoleh harga mean $(M)=27,78$; median $(\mathrm{Me})=27$; modus $(\mathrm{Mo})=27$; standar deviasi $(\mathrm{SD})=1,996$. Hasil observasi siklus I pada sikap belajar siswa yang ditunjukan melalui kemampuan manajerial siswa diperoleh harga mean $(\mathrm{M})=18,63$; median $(\mathrm{Me})=18$; $\operatorname{modus}(\mathrm{Mo})=18$; standar deviasi $(\mathrm{SD})=2,028$.

Tindakan pada siklus II bertujuan untuk meningkatkan sikap belajar siswa melalui motivasi, kreativitas, dan kemampuan manajerial siswa secara umum terdiri dari: memperbanyak jumlah kelompok dalam kelas dengan masing-masing kelompok beranggotakan empat siswa, memberikan pendampingan pada siswa yang mengalami kesulitan materi pelajaran, mewajibkan setiap kelompok untuk mempresentasikan hasil diskusi di depan kelas, memberikan tugas yang berbeda-beda pada setiap kelompok, memberikan kesempatan pada semua kelompok untuk mencari sumber ide melalui pemanfaatan laptop serta dilakukan pendampingan pada kelompok yang dirasa masih kurang, membagi tugas dan tanggung-jawab siswa pada masingmasing kelompok, dan membuat kesepakatan bersama untuk wajib mempresentasikan hasil diskusi di depan kelas.

Dari hasil observasi siklus II pada sikap belajar siswa yang ditunjukan melalui motivasi siswa diperoleh harga mean $(\mathrm{M})=62,34$; median $(\mathrm{Me})=61$; modus $(\mathrm{Mo})=61$; standar deviasi $(\mathrm{SD})=2,059$. Hasil observasi siklus II pada sikap belajar siswa yang ditunjukan melalui kreativitas siswa diperoleh harga mean $(M)=46,64$; median $(\mathrm{Me})=46$; modus $(\mathrm{Mo})=45$; standar deviasi $(\mathrm{SD})=1,930$. Hasil observasi siklus II pada sikap belajar siswa yang ditunjukan melalui kemampuan manajerial siswa diperoleh harga mean $(\mathrm{M})=$ 27,56; median $(\mathrm{Me})=27$; modus $(\mathrm{Mo})=26$; standar deviasi $(\mathrm{SD})=2,435$.

Tindakan pada siklus III dilakukan untuk menyelesaikan permasalahan yang muncul saat pembelajaran di siklus II serta meningkatkan sik:ap belajar siswa, secara umum antara lain: memberikan kesempatan kepada siswa yang mengalami kesulitan untuk mengutarakan pendapat di dalam diskusi kelompok serta memperoleh pendampingan dari guru, memberikan penekanan pada setiap kelompok agar hasil diskusi yang akan disampaikan di depan kelas tidak memiliki kesamaan dengan kelompok lain serta guru melakukan supervisi terlebih dahulu, memberikan pemahaman kepada siswa akan jobdesk masing-masing siswa dalam kelompok, agar ada tugas dan tanggung-jawab.

Dari hasil observasi siklus III pada sikap belajar siswa yang ditunjukan melalui motivasi siswa diperoleh harga mean $(\mathrm{M})=69$; median $(\mathrm{Me})=68,50$; modus $(\mathrm{Mo})=68$; standar deviasi $(\mathrm{SD})=3,445$. Hasil observasi siklus III pada sikap belajar siswa yang ditunjukan melalui kreativitas siswa diperoleh harga mean $(\mathrm{M})=57,06$; median $(\mathrm{Me})=57$; modus $(\mathrm{Mo})=57$; standar deviasi $(\mathrm{SD})=2,501$. Hasil observasi siklus III pada sikap belajar siswa yang ditunjukan melalui kemampuan manajerial siswa diperoleh harga mean $(\mathrm{M})=$ 33,19 ; median $(\mathrm{Me})=33$; modus $(\mathrm{Mo})=32$; standar deviasi $(\mathrm{SD})=1,857$. Berikut kategori deskripsi untuk masing-masing aspek tinjauan dari pra siklus, siklus I, siklus II, dan siklus III: 


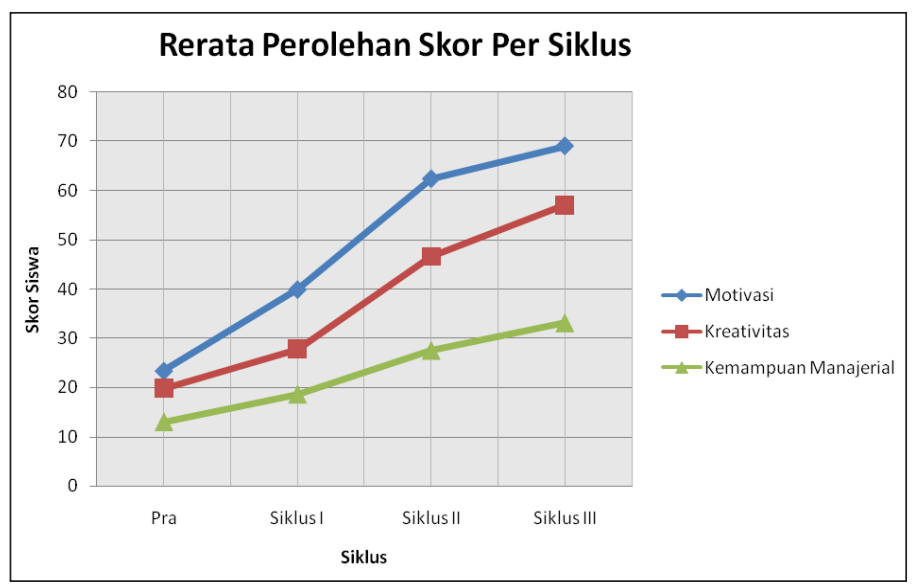

Gambar 2. Rerata Perolehan Skor Per Siklus

Tabel 1. Kategori Deskripsi untuk Motivasi Siswa

\begin{tabular}{lcccc}
\hline Kategori & $\begin{array}{c}\text { Frek } \\
\text { PS }\end{array}$ & $\begin{array}{c}\text { Frek } \\
\text { S-I }\end{array}$ & $\begin{array}{c}\text { Frek } \\
\text { S-II }\end{array}$ & $\begin{array}{c}\text { Frek } \\
\text { S-III }\end{array}$ \\
\hline Sangat Tinggi & 0 & 0 & 8 & 30 \\
Tinggi & 0 & 0 & 24 & 2 \\
Sedang & 0 & 7 & 0 & 0 \\
Rendah & 5 & 25 & 0 & 0 \\
Sangat Rendah & 27 & 0 & 0 & 0 \\
Total & 32 & 32 & 32 & 32 \\
\hline
\end{tabular}

Tabel 2. Kategori Deskripsi untuk Kreativitas Siswa

\begin{tabular}{lcccc}
\hline \multirow{2}{*}{ Kategori } & $\begin{array}{c}\text { Frek } \\
\text { PS }\end{array}$ & $\begin{array}{c}\text { Frek } \\
\text { S-I }\end{array}$ & $\begin{array}{c}\text { Frek } \\
\text { S-II }\end{array}$ & Frek \\
& S-III \\
\hline Sangat Tinggi & 0 & 0 & 0 & 29 \\
Tinggi & 0 & 0 & 30 & 3 \\
Sedang & 0 & 0 & 2 & 0 \\
Rendah & 7 & 32 & 0 & 0 \\
Sangat Rendah & 25 & 0 & 0 & 0 \\
Total & 32 & 32 & 32 & 32 \\
\hline
\end{tabular}

Tabel 3. Kategori Deskripsi untuk Kemampuan Manajerial Siswa

\begin{tabular}{lcccc}
\hline Kategori & $\begin{array}{c}\text { Frek } \\
\text { PS }\end{array}$ & $\begin{array}{c}\text { Frek } \\
\text { S-I }\end{array}$ & $\begin{array}{c}\text { Frek } \\
\text { S-II }\end{array}$ & Frek \\
& S-III \\
\hline Sangat Tinggi & 0 & 0 & 1 & 5 \\
Tinggi & 0 & 0 & 13 & 27 \\
Sedang & 2 & 3 & 18 & 0 \\
Rendah & 4 & 29 & 0 & 0 \\
Sangat Rendah & 26 & 0 & 0 & 0 \\
Total & 32 & 32 & 32 & 32 \\
\hline
\end{tabular}

Rerata peningkatan kualitas pembelajaran yang terjadi saat implementasi tindakan mulai dari kondisi pra siklus, siklus I, siklus II, dan siklus III pada mata pelajaran Prakarya dan Kewirausahaan siswa kelas X paket keahlian Kimia Industri di SMK Negeri 2 Depok melalui sikap belajar pada aspek tinjauan motivasi secara berturut-turut sebesar 23,$375 ; 39,875$; 62,344; dan 69.

Aspek tinjauan kreativitas siswa dari hasil observasi mulai kondisi pra siklus, siklus I, siklus II, dan siklus III secara berturut-turut sebesar 19,75; 27,78; 46,625; dan 57,06. Aspek tinjauan kemampuan manajerial siswa dari hasil observasi mulai kondisi pra siklus, siklus I, siklus II, dan siklus III secara berturutturut sebesar $13 ; 18,625 ; 27,56$; dan 33,187. Berikut grafik rerata perolehan skor per siklus pada aspek tinjauan motivasi, kreativitas, dan kemampuan manajerial siswa untuk mata pelajaran Prakarya dan Kewirausahaan.

Peningkatan sikap belajar siswa pada aspek tinjauan motivasi, kreativitas, dan kemampuan manajerial siswa mengalami peningkatan terbesar pada saat siklus ke-II. Hal ini dikarenakan, pada implementasi tindakan siklus ke-II siswa dibagi ke dalam delapan kelompok, dimana dalam satu kelompok hanya terdapat empat orang siswa, siswa telah terbiasa dengan membuat rencana penyelesaian tugas yang telah disesuaikan dengan job desk masing-masing.

Berdasarkan hasil observasi pada siklus keII, siswa terlihat lebih antusias dalam mengikuti pelajaran. Siswa terlihat aktif berdiskusi dalam 
kelompok dengan jumlah anggota kecil, selain itu tidak didapatkan ketergantungan antar siswa dalam menyelesaikan tugas. Siswa merasa lebih nyaman dengan jumlah anggota empat orang, dan hampir semua siswa dapat berpendapat dalam diskusi.

Peningkatan pada siklus ke-III tidak sebesar seperti peningkatan siklus ke-II, hal ini dikarenakan implementasi tindakan sudah berada pada kondisi optimal. Siklus ke-III dilaksanakan sebagai salah satu upaya untuk mengetahui apakah terdapat peningkatan sikap belajar yang signifikan atau tidak.

Proses peningkatan sikap belajar siswa melalui aspek tinjauan motivasi, kreativitas, dan kemampuan manajerial siswa terdiri dari empat fase. Fase pertama adalah penyampaian tujuan dan memotivasi siswa, pada fase ini siswa melakukan aktivitas berupa mencermati materi yang disampaikan oleh guru berupa sumber daya yang dibutuhkan dalam membuat karya rekayasa sebagai alat komunikasi sederhana, melakukan tanya-jawab perihal materi pelajaran berupa sumber daya yang dibutuhkan dalam membuat karya rekayasa sebagai alat komunikasi sederhana, dan siswa membentuk kelompok berdasarkan kesepakatan bersama yang berjumlah tiga kelompok.

Fase ke dua adalah penyajian informasi, pengamatan, dantanyajawab. Pada faseinisiswa melakukan aktivitas berupa siswa mengamati contoh penyusunan jadwal pengerjaan proyek dan membuat jadwal pengerjaan proyek sesuai dengan kebutuhan masing-masing kelompok, siswa menggali informasi dan berdiskusi dalam kelompok perihal sumber daya yang dibutuhkan dalam membuat karya rekayasa sebagai alat komunikasi sederhana, siswa melakukan konsultasi kepada guru tentang sumber daya yang dibutuhkan dalam membuat karya rekayasa sebagai alat komunikasi sederhana.

Faseketigaadalahmemberikankesempatan kepada siswa untuk mengumpulkan informasi, berdiskusi, unjuk kerja, dan menyampaikan hasil diskusi. Pada fase ini siswa melakukan aktivitas berupa mengidentifikasi sumber daya yang dibutuhkan dalam membuat karya rekayasa sebagai alat komunikasi sederhana, berdiskusi serta menyimpulkan hasil diskusi yang didapatkan saat mencari informasi tentang identifikasi sumber daya yang dibutuhkan dalam membuat karya rekayasa sebagai alat komunikasi sederhana sesuai dengan kelompok masing-masing, dan membuat laporan hasil diskusi untuk dipaparkan di depan kelas sesuai dengan kelompok masing-masing.

Fase terakhir adalah penguatan materi dan penyimpulan. Pada fase ini siswa melakukan aktivitas berupa tanya jawab perihal materi pelajaran tentang sumber daya yang dibutuhkan dalam membuat karya rekayasa sebagai alat komunikasi sederhana yang diwakili oleh anggota kelompok, serta setiap kelompok menyimpulkan hasil yang didapatkan pada pertemuan pada siklus I.

Besaran peningkatan motivasi belajar, kreativitas berpikir, dan kemampuan manajerial siswa yang diperoleh secara berurutan mulai dari observasi yang telah dilakukan pada kegiatan pra siklus, siklus I, siklus II, dan siklus III didapatkan rerata sebesar 41,611; 36,$053 ; 9,551 ; 29,239 ; 40,458 ; 18,231 ; 30,774$; 32,$311 ; 16,996$.

Peningkatan terbesar, berdasarkan perolehan rerata siswa terjadi pada siklus I untuk aspek tinjauan motivasi belajar siswa; siklus II untuk aspek tinjauan kreativitas berpikir dan kemampuan manajerial siswa. Hal ini dikarenakan siswa termotivasi oleh penyampaian materi pelajaran yang bersifat aktif dengan melibatkan siswa dalam penyusunan rencana belajar hingga pada penyimpulan materi yang telah didapatkan pada pertemuan siklus II. Peningkatan pada siklus III sudah tidak sebesar peningkatan siklus II, hal ini dikarenakan siswa telah mengalami proses pembentukan sikap belajar yang konsisten atau pemberian tindakan pada siklus III sudah tidak mengalami signifikansi lagi.

Proses peningkatan kualitas pembelajaran pada mata pelajaran Prakarya dan Kewirausahaan siswa kelas X paket keahlian Kimia Industri di SMK Negeri 2 Depok melalui sikap belajar dengan aspek tinjauan motivasi, kreativitas, dan kemampuan manajerial siswa secara umum dari siklus I, siklus II, dan siklus III terbentuk melalui empat fase. Ke empat fase tersebut, terdiri atas: 1) penyampaian 


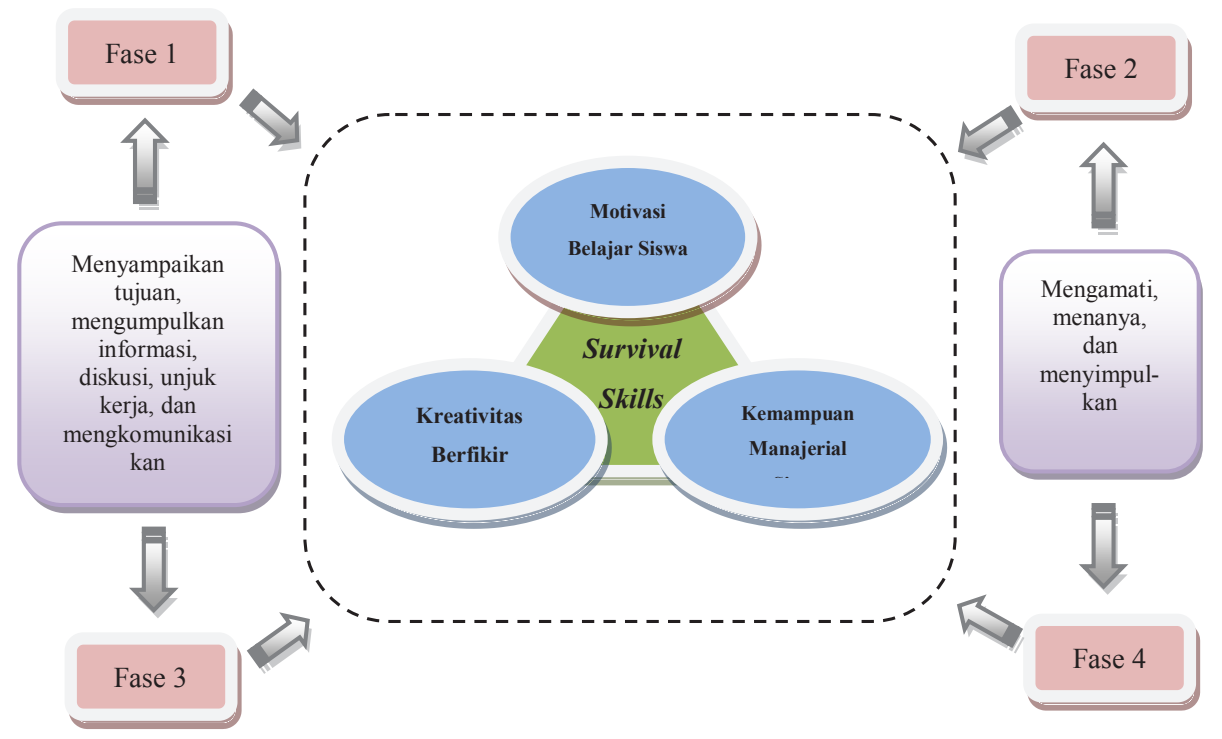

Gambar 2. Konseptual Temuan Penelitian

tujuan pembelajaran dan melakukan apersepsi kepada siswa dengan cara memotivasi di awal pembelajaran; 2) menyajikan informasi, mengamati, dan menanya; 3) mengumpulkan informasi, berdiskusi, unjuk kerja, dan menyampaikan hasil diskusi; serta 4) penguatan materi dan simpulan pembelajaran. Ke empat fase tersebut digunakan sebagai upaya untuk meningkatkan kualitas pembelajaran pada mata pelajaran Prakarya dan Kewirausahaan melalui sikap belajar siswa.

Penggunaan ke empat fase dalam implementasi tindakan pada siklus I, siklus II, dan siklus III telah disesuaikan dengan kompetensi dasar yang harus dikuasai siswa yaitu mengidentifikasi sumber daya yang dibutuhkan dalam mendukung proses produksi karya rekayasa alat komunikasi sederhana dan membuat desain/karya rekayasa alat komunikasi sederhana. Fase ke dua dan fase ke tiga yang digunakan dalam implementasi tindakan siklus I, siklus II, dan siklus III telah sesuai dengan ciri khas rencana pelaksanaan pembelajaran pada kurikulum 2013 yang terdiri dari $5 \mathrm{M}$ (mengamati, menanya, mengumpulkan informasi, mengasosiasi, dan mengkomunikasikan).

Fase pertama berupa penyampaian tujuan pembelajaran dan melakukan apersepsi kepada siswa dengan cara memotivasi di awal pembelajaran. Implementasi fase pertama tergambarkan melalui pemberian kesempatan kepada siswa untuk mengetahui secara utuh tujuan pembelajaran yang akan dicapai pada kegiatan belajar mengajar. Siswa diberikan rangsangan berupa pertanyaan-pertanyaan menyangkut materi ajar. Pada fase pertama didapatkan komunikasi aktif antara siswa dengan guru, selanjutnya guru memberikan motivasi belajar kepada siswa dengan cara menjelaskan seberapa pentingnya materi yang akan dibahas. Alokasi waktu yang digunakan untuk mengimplementasikan fase pertama ini adalah 15 menit. Di akhir fase pertama, guru memberikan contoh riil berupa alat komunikasi sederhana (HT) yang digunakan siswa sebagai bahan identifikasi sumber daya yang dibutuhkan dalam mendukung proses produksi karya rekayasa.

Fase ke dua, siswa melakukan pengamatan pada contoh yang diberikan oleh guru. Implementasi fase ke dua menghasilkan kegiatan diskusi yang dilakukan oleh siswa secara tim/kelompok tentang identifikasi sumber daya yang dibutuhkan dalam mendukung proses produksi karya rekayasa berupa HT. Guru memberikan rangsangan berupa pertanyaan kepada setiap kelompok untuk mengukur seberapa dalam siswa mengamati dan mendeskripsikan hasil pengamatan yang telah dilakukan. 
Fase ke tiga, siswa melakukan diskusi, unjuk kerja, dan diberikan kesempatan untuk mempresentasikan hasil diskusi. Implementasi fase ke tiga siswa terlihat lebih aktif dalam kegiatan belajar mengajar, hal ini ditunjukkan melalui terselesaikannya tugas yang diberikan oleh guru dalam pertemuan tersebut. Setiap kelompok menghasilkan karya berupa desain rekayasa alat komunikasi sederhana yang berbeda-beda sesuai dengan kolompok masing-masing. Di akhir fase ke tiga, siswa menjelaskan hasil diskusi kelompok di depan kelas. Presentasi tersebut menunjukkan, siswa dalam kelompok lain turut antusias terhadap paparan yang dijelaskan oleh temannya, hal ini dibuktikan melalui terdapat beberapa pertanyaan dan saran yang diajukan oleh siswa mengenai paparan yang disampaikan temannya di depan kelas.

Fase ke empat, secara umum dilakukan oleh guru melalui penguatan materi dan pemberian simpulan atas pembelajaran yang telah disampaikan. Pada kesempatan fase ke empat, siswa terlihat aktif dalam memberikan simpulan pembelajaran. Melalui penyampaian simpulan, guru bisa mengukur seberapa besar ketercapaian pembelajaran yang dikuasai siswa. Berikut skema konseptual temuan penelitian yang dapat dijelaskan melalui gambar 2.

Salah satu keterbatasan dalam pelaksanaan penelitian ini adalah aspek waktu. Waktu yang digunakan untuk implementasi penelitian hanya selama tiga bulan. Satu bulan dilaksanakan di sekolah dalam hal ini adalah saat proses pembelajaran mata pelajaran Prakarya dan Kewirausahaan. Dua bulan digunakan untuk pengembangan rencana pelaksanaan pembelajaran dan instrumen observasi yang akan digunakan untuk mengukur proses peningkatan sikap belajar siswa pada mata pelajaran Prakarya dan Kewirausahaan.

Kualitas pembelajaran yang ditinjau dalam penelitian ini terbatas pada sikap belajar siswa saat mengikuti kegiatan belajar mengajar mata pelajaran Prakarya dan Kewirausahaan. Peningkatan kualitas pembelajaran ditinjau pada aspek siswa saja, masih ada aspek tinjauan lain seperti guru serta sarana dan prasarana sekolah.
Penggunaan metode pembelajaran pada mata pelajaran Prakarya dan Kewirausahaan ini hanya terbatas pada peminatan rekayasa saja. Masih ada peminatan lain seperti kerajinan, budidaya, dan pengolahan.

\section{SIMPULAN DAN SARAN}

\section{Simpulan}

Simpulan dari penelitian ini antara lain: terdapat peningkatan sikap belajar siswa melalui motivasi, kreativitas, dan kemampuan manajerial siswa pada mata pelajaran Prakarya dan Kewirausahaan kelas X Kimia Industri di SMKN 2 Depok melalui penggunaan metode pembelajaran CLTSMK. Rerata peningkatan sikap belajar siswa melalui motivasi, kreativitas, dan kemampuan manajerial siswa secara berturut-turut mulai dari siklus I, siklus II, siklus III sebesar 41,611\%, 36,053\%, dan $9,551 \% ; 29,239 \%, 40,458 \%$, dan $18,231 \%$; serta $30,774 \%$, 32,311\%, dan 16,996\%.

Proses upaya peningkatan sikap belajar siswa yang ditunjukkan melalui motivasi, kreativitas, dan kemampuan manajerial siswa kelas X Kimia Industri di SMKN 2 Depok pada kompetensi dasar mengidentifikasi sumber daya dan membuat desain karya rekayasa melalui penggunaan metode pembelajaran CLTSMK pada mata pelajaran Prakarya dan Kewirausahaan terdiri atas empat fase, fase pertama adalah penyampaian tujuan dan memotivasi siswa; fase ke dua adalah penyajian informasi, pengamatan, dan tanya jawab; fase ke tiga adalah memberikan kesempatan untuk mengumpulkan informasi, berdiskusi, unjuk kerja, dan menyampaikan hasil diskusi; serta fase terakhir adalah penguatan materi dan penyimpulan.

\section{Saran}

Temuan-temuan yang didapatkan dari hasil penelitian ini masih perlu dikembangkan, berikut saran dari peneliti: pertama, perlu adanya uji coba penggunaan metode CLTSMK untuk sekolah lain, dimana pasti akan menemukan permasalahanpermasalahan baru dalam implementasi sehingga akan menyempurnakan metode tersebut. Kedua, pada mata pelajaran Prakarya 
dan Kewirausahaan tidak hanya semata pada bidang keahlian teknologi rekayasa, melainkan ada peminatan pada budidaya, kerajinan, dan pengolahan, tentu pada setiap peminatan mata pelajaran Prakarya dan Kewirausahaan di SMK harus memiliki metode pembelajaran yang berbeda dan disesuaikan dengan kompetensi yang dimiliki. Ketiga, perlu adanya kolaborasi antara guru produktif dengan guru pengampu mata pelajaran Prakarya dan Kewirausahaan, hal ini dikarenakan pembelajaran akan lebih optimal apabila guru pengampu mata pelajaran memiliki kompetensi yang baik dalam setiap pokok bahasan peminatan (rekayasa, budidaya, kerajinan, dan pengolahan). Keempat, perlu adanya perhatian dan bantuan dari pemerintah daerah untuk turut andil dalam upaya meningkatkan kemampuan wirausaha.

\section{DAFTAR PUSTAKA}

Andler,N.(2011).ToolsforProject Management Workshop and Consulting: A Must have Compendium of Essensial tools and Techniques. Zweigniederlassung: Erlangen.

Aprilianty, E. (2012). Pengaruh Kepribadian Wirausaha, Pengetahuan Kewirausahaan, dan Lingkungan terhadap Minat Berwirausaha Siswa SMK. Jurnal Pendidikan Vokasi, 3, pp.311-324.

Badan Pusat Statistik. (2014). Pengangguran Terbuka menurut Pendidikan Tertinggi yang Ditamatkan Tahun 2004-2014. Jakarta.

Ben-Daya, M,. et. all. (2009). Handbook of Maintenance Management and Engineering. London: Springer Dordrecht.

Hartono, W. (2011). Pengembangan Technopreneurship: Upaya Peningkatan Daya Saing Bangsa di Era Global. Jurnal pada SEMANTIK, 1, pp.1-6.

Jusoh, S. (2011). Incubators as Catalysts in Developing High Technology Businesses: Malaysia's Experience. Journal ATDF, 3, pp.25-29.

Kearins, K., \& Springett, D. (2003). Educating for Sustainbility: Developing Critical
Skills. Journal of Management Education, 27, pp.188-204.

Kelly, J. (2011). Value Management of Construction Projects. Victoria: Blackell Science.

Kementerian Pendidikan dan Kebudayaan. (2013). Buku Guru Prakarya dan Kewirausahaan. Jakarta: Kemendikbud.

Lastariwati, B. (2012). Pentingnya Kelas Kewirausahaan pada SMK Pariwisata. Jurnal Pendidikan Vokasi, 1, pp.71-81.

Lau, J. Y. F. (2011). An Introdustion to Critical Thinking and Creativity: Think More, Think Better.

Mertler, C. A. (2011). Action Research: Mengembangkan Sekolah Memberdayakan Guru. Yogyakarta: Pustaka Pelajar

Nasution, A. H., Arifin, D., \& Suef, M. (2007). Entrepreneurship: Membangun Spirit Teknopreneurship. Yogyakarta: Andi.

Piirto, J. (2011). Creativity for $21^{\text {ST }}$ Century Skills: How to Embed Creativity into the Curriculum. New York: Ashland University.

Pope, R. (2005). Creativity: Theory, History, Practice. New York: Routledge.

Presiden. (2013). Rencana Strategis Direktorat Jenderal Pendidikan Menengah Tahun 2010-2014.

Sardiman, A. M. (2012). Interaksi \& Motivasi Belajar Mengajar. Depok: Rajagrafindo Persada.

Slavin, R. E. (2005). Cooperative Learning: Teori, Riset, dan Praktik. Bandung: Nusa Media.

Timmons, J. A., \& Spinelli, S. (2008). New Venture Creation Entrepreneurship for the $21^{s t}$ Century. Yogyakarta: Andi.

Yusuf. (2012). Penerapan Pembelajaran Kooperatif untuk Meningkatkan Hasil Belajar Siswa Pada Mata Diklat Kewirausahaan di SMK Ardjuna 2 Malang. Jurnal Fakultas Ekonomi dan Bisnis UNESA, 3, pp.8-22. 